\title{
KSIĄDZ PROFESOR WINCENTY WILHELM MYSZOR
}

Ks. Wincenty Wilhelm Myszor urodził się 22 maja 1941 r. w rodzinie robotniczej w Chełmie Śląskim, gdzie również uczęszczał do szkoły podstawowej. Dalszą naukę kontynuował w liceum mysłowickim im. Tadeusza Kościuszki, po którego ukończeniu w 1959 r. wstąpił do Wyższego Śląskiego Seminarium Duchownego w Krakowie, gdzie podjął 6-letnie studia teologiczne, ukoronowane święceniami kapłańskimi 6 czerwca 1965 r. w katedrze katowickiej z rąk ks. biskupa Herberta Bednorza; uczęszczając w czasie tych studiów na seminarium ks. prof. dr. hab. Mariana Michalskiego w Krakowie uzyskał magisterium z teologii na podstawie pracy pt. Pojęcie herezji $w$ listach św. Cypriana (wydanej później w: STV 9:1971, 147-190). Po święceniach kapłańskich przez dwa lata (1965-1967) pracował jako wikariusz w parafii św. Jana i Pawła w Katowicach-Dębie kontynuując równocześnie specjalistyczne studia teologiczne najpierw (1965-1967) na Wydziale Teologicznym Papieskiej Akademii Teologicznej w Krakowie, gdzie uzyskał stopień licencjata kanonicznego z teologii, a następnie (1967-1969) na Wydziale Teologicznym Akademii Teologii Katolickiej w Warszawie, specjalizując się w historii Kościoła i literaturze wczesnochrześcijańskiej. W 1969 r. podjął pracę naukowo-dydaktyczną jako asystent w Katedrze Patrologii na Wydziale Teologicznym ATK, gdzie po niespełna czterech latach doktoryzował się z teologii 11 czerwca 1973 r. na podstawie rozprawy pt. Gnostycyzm w tekstach z Nag Hammadi, napisanej pod kierunkiem ks. prof. dr.hab. Henryka Boguckiego (opublikowanej później w: „Studia Antiquitatis Christianae” 1/2:1977, 121-266).

\section{Działalność naukowo-dydaktyczna i administracyjno-organizacyj-} na. Działalność naukowo-dydaktyczna Księdza Profesora Myszora, jak również administracyjno-organizacyjna, związana jest głównie z dwoma ośrodkami naukowymi: Akademią Teologii Katolickiej w Warszawie (1969-2001) oraz Wydziałem Teologicznym Uniwersytetu Śląskiego w Katowicach (od 2001 roku).

Najpierw po ukończeniu studiów i doktoracie prowadził pracę naukowodydaktyczną w Katedrze Patrologii na Wydziale Teologicznym ATK jako asystent, potem od $1973 \mathrm{r}$. jako adiunkt, po habilitacji z teologii 6 grudnia $1982 \mathrm{r}$. na podstawie dorobku naukowego i rozprawy pt. Anapausis w teologii chrześcijańskich gnostyków (opublikowanej później: Warszawa 1984, ss. 287) jako docent, a od 28 lutego 1994 r. jako tytularny profesor nauk humanistycznych. Gdy w 1987 r. z części Wydziału Teologicznego ATK stworzono Wydział Kościelnych Nauk Historycznych i Społecznych, Ksiądz Myszor przeszedł na no- 
wopowstały Wydział i pracował w nim w latach 1987-2001 r., najpierw jako docent, następnie od 1990 r. na stanowisku profesora nadzwyczajnego, a od 1994 r. na stanowisku profesora zwyczajnego (Wydział ten w 1999 r. wraz z przekształceniem Akademii Teologii Katolickiej w Uniwersytet Kardynała Stefana Wyszyńskiego został przekształcony w Wydział Nauk Historycznych i Społecznych).

Jako pracownik ATK w Warszawie w latach 1984-1987 pełnił funkcje prodziekana Wydziału Teologicznego, a w roku akademickim 1987/88 był prodziekanem Wydziału Kościelnych Nauk Historycznych i Społecznych. W pierwszych latach istnienia tego Wydziału był jego współorganizatorem oraz współautorem (wraz z ks. prof. Emilem Stanulą) programu nauczania w zakresie historii literatury wczesnochrześcijańskiej. W latach 1988-1993, przez dwie kadencje, był dziekanem wspomnianego Wydziału, natomiast w latach 1993-1995 prorektorem Akademii Teologii Katolickiej w Warszawie. W latach 1987-1996 kierował Katedrą Historii Literatury i Teologii Kościoła Starożytnego, a następnie w latach 1996-2001 Katedrą Historii Kościoła Starożytnego. W latach 1999-2001 był także dyrektorem Instytutu Nauk Historycznych Uniwersytetu Kardynała Stefana Wyszyńskiego w Warszawie. Równolegle z pracą w Warszawie, w latach 1972-2001 był wykładowcą literatury wczesnochrześcijańskiej (patrologii) w Wyższym Śląskim Seminarium Duchownym w Katowicach.

Od 2000 r. prace administracyjne Księdza Profesora Myszora, później także naukowo-dydaktyczne, skupiały się przede wszystkim na nowopowstałym Wydziale Teologicznym UŚ w Katowicach. Wydział ten został powołany z inicjatywy Senatu UŚ przy współpracy kościelnych władz Kongregacji d/s Wychowania Katolickiego (w Rzymie) i lokalnej władzy arcybiskupa katowickiego. W 1998 r. ks. abp Damian Zimoń upoważnił Księdza Myszora do prowadzenia prac przygotowawczych do powołania Wydziału Teologicznego w Uniwersytecie Śląskim. Pracę tę w Uniwersytecie Śląskim rozpoczął w 2001 r. jako dziekan - organizator Wydziału Teologicznego (wybrany dziekanem Wydziału na ostatni rok kadencji 1999-2002); w latach 2002-2008, przez dwie kadencje (2002-2005 i 2005-2008) był dziekanem Wydziału Teologicznego. W tym okresie Wydział Teologiczny uzyskał prawo doktoryzowania (2002 r.) oraz prawo habilitowania w naukach teologicznych (2008 rok).

Swoje badania naukowe i działalność dydaktyczną prowadził Ksiądz Myszor w Zakładzie Patrologii (jako kierownik Zakładu), a po jego przekształceniu według programu badawczego i dydaktycznego w Zakładzie Teologii Patrystycznej i Historii Kościoła. Będąc dziekanem Wydziału pełnił także w latach 2005-2008 funkcję kuratora Zakładu Filozofii Chrześcijańskiej.

2. Zainteresowania naukowe. W pracy naukowo badawczej Ksiądz Profesor Myszor zajmuje się głównie literaturą gnostycką i polemiką z gnostycyzmem w pismach Ireneusza z Lyonu i Tertuliana; interesuje go również życie 
społeczne chrześcijan w II i III wieku. Z badań nad gnostycyzmem najważniejsze są jego tłumaczenia na język polski koptyjskich tekstów Biblioteki z Nag Hammadi oraz ich krytyczne, historyczne i teologiczne opracowania. $\mathrm{Na}$ marginesie prac naukowych nad źródłami gnostyckimi zajął się również językiem koptyjskim: we współpracy z profesorką Albertyną Dembską przygotował pierwszy w Polsce Podręczny słownik języka koptyjskiego (Warszawa 1996) oraz Chrestomatia koptyjska (Warszawa 1998). Jest także autorem podręcznika do nauki języka koptyjskiego: Język koptyjski. Kurs podstawowy dialektu saidzkiego. Opracowanie studyjne (Warszawa 1998).

3. Działalność dydaktyczna. Oprócz wykładów kursorycznych z historii Kościoła i patrologii, na poziomie magisterskim oraz doktoranckim, Ksiądz Profesor Myszor prowadził wykłady monograficzne, w których podejmował zagadnienia gnostycyzmu, manicheizmu, chrześcijańskiej duchowości Wschodu oraz monastycyzmu wschodniego. Od 1976 r. prowadził także zajęcia fakultatywne z języka koptyjskiego w Akademii Teologii Katolickiej w Warszawie, a od 2001 r. w Wydziale Teologicznym UŚ; przez cztery semestry (w latach 1998-2000) uczył także tego języka w Katolickim Uniwersytecie Lubelskim.

\section{Udział w kształceniu kadry dydaktycznej:}

A. Promotor w przewodach doktorskich. Ksiądz Profesor Myszor wypromował siedmiu doktorów, w tym pięciu na Wydziale Kościelnych Nauk Historycznych i Społecznych ATK - rozprawy z dziedziny historii starożytnego Kościoła:

1. Nieścior Leon ks., Anachoreza w pismach Ewagriusza z Pontu, Warszawa 1993, ss. 211 (praca opublikowana);

2. Czyżewski Bogdan ks., Elementy chrystologii w komentarzu „Do Zachariasza” Dydyma Aleksandryjskiego, Warszawa 1995, ss. 196 (praca opublikowana);

3. Masny Marcin, Chrześcijanie i stużba wojskowa do końca IV wieku, Warszawa 1997, ss. 231 (praca nieopublikowana);

4. Uciecha Andrzej ks., Nauka ascetyczna w pismach Afrahata, Warszawa 2000, ss. 210 (praca opublikowana);

5. Szmurło Roman ks., Życie monastyczne w pismach Szenutego z Atripe, Warszawa 2000, ss. 337 (praca opublikowana);

Ponadto dwóch doktorów nauk teologicznych w Wydziale Teologicznym Uniwersytetu Śląskiego w Katowicach:

1. Zarzeczny Rafał SJ, Melchizedek w literaturze okresu wczesnego chrześcijaństwa, Katowice 2006, ss. 432, (praca opublikowana w 2009 r.); 
2. Kamczyk Wojciech ks., Tota Paschalis Solemnitas. Teologia i duszpasterstwo w kazaniach i homiliach św. Augustyna, Katowice 2011, ss. 384, (praca opublikowana).

Obecnie prowadzi 3 otwarte przewody doktorskie: jeden na Wydziale Teologicznym UŚ, jeden na Wydziale Nauk Społecznych UŚ (drugi promotor prof. dr hab. Ewa Wipszycka-Brawo w Academia Artes Liberales przy Uniwersytecie Warszawskim) oraz jeden na Wydziale Filologicznym US.

\section{B. Recenzent prac promocyjnych:}

\section{a. Doktoraty:}

1. Grzywaczewski Józef ks., Modlitwa w duchu agape wedtug Klemensa Aleksandryjskiego, KUL, Lublin 1987 (promotor F. Drączkowski).

2. Czapiga Tadeusz ks., Nauka Grzegorza z Elwiry o człowieku, ATK, Warszawa 1988 (promotor E. Stanula).

3. Rzodkiewicz Leopold ks., Chrystus przepowiadany Hellenom $w$ pismach Klemensa Aleksandryjskiego, KUL, Lublin 1991 (promotor F. Drączkowski).

4. Grabowski Stefan, Duszpasterska działalność Chromacjusza z Akwilei, KUL, Warszawa 1992 (promotor E. Stanula).

5. Drążek Dariusz ks., Pojęcie ,,disciplina” w pismach św. Cypriana, KUL, Lublin 1994 (promotor F. Drączkowski).

6. Łatak Kazimierz, Prepozytura Bożego Ciała Kanoników Regularnych Laterańskich w Kazimierzu pod Krakowem do końca XVI w., ATK, Warszawa 1998, (promotor J. Zbudniewek).

7. Rzymowska Luiza, Istota gnostycyzmu $w$ świetle interpretacji pojęcia prawdy na przykładzie wybranych pism apokryficznych, Wydział Historyczny UWr, Wrocław 1999 (promotor J. Woronczak).

8. Żurek Magdalena, Kościoły i zespoty klasztorne na terenie Oazy Fajum między IV i XIV wieku, Wydział Historyczny UW, Warszawa 2000 (promotor E. Jastrzębowska).

9. Mateja Leszek ks., Oblicze miłosierdzia. Historyczne uwarunkowania rozwoju doktryny o miłosierdziu. Studium dzieł Tertuliana i świętego Cypriana, Wydział Teologiczny PAT w Krakowie, Kraków 2002 (promotor E. Staniek).

10. Nakonieczny Rafał, Terminologia antropologiczna $w$,Komentarzu do Księgi Rodzaju” Dydyma Aleksandryjskiego, Wydział Filologiczny UŚ, Katowice 2004 (promotor J. Rostropowicz).

11. Przyszychowska Marta, Nauka o łasce $w$ dziełach świętego Grzegorza z Nyssy, Wydział Teologiczny UKSW, Warszawa 2004 (promotor J. Salij).

12. Babiarz Grzegorz ks., Grzech i nawrócenie w życiu ochrzczonych. Studium „Komentarza” Ambrozjastra do Listów św. Pawła, PAT, Kraków 2006 (promotor E. Staniek). 
13. Krzysztof Modras, Omelia copta attribuia a Demetrio di Antiochia, Roma 1995 (nostryfikacja doktoratu na Wydziale Teologii KUL, Lublin 2009).

\section{b. Habilitacje:}

1. Godlewski Włodzimierz, Le monastère de St. Phoibammon, Varsovie 1986, ss.168; kolokwium: Wydział Historyczny UW, Warszawa 1985.

2. Pietras Henryk SJ, Jedność Boga, jedność świata i jedność Kościoła. Studium fragmentów z pism Dionizego Aleksandryjskiego, Kraków 1990, ss. 194; kolokwium: Wydział Teologiczny PAT, Kraków 1990.

3. Naumowicz Józef ks., Geneza chrześcijańskiej rachuby lat. Historyczno-teologiczne podstawy systemu Dionizego Mniejszego, Tyniec - Kraków 2000, ss. 327; kolokwium: Wydział Nauk Historycznych i Społecznych UKSW, Warszawa 2000.

4. Kołosowski Tadeusz SDB, Od wolności wyboru wyznania do przymusu religijnego. Ewolucja pogląów Augustyna z Hippony podczas schizmy donatystycznej w Afryce Rzymskiej, Piła 2000, ss. 312; kolokwium: Wydział Nauk Historycznych i Społecznych UKSW, Warszawa 2000.

5. Słomka Jan ks., Pokarm i ofiara, Refleksja eucharystyczna wczesnych Ojców greckich, Łódź 2000, ss. 236; kolokwium: Wydział Teologiczny PAT, Kraków 2001.

6. Widok Norbert, Physis w pismach Grzegorza z Nazjanzu, Studium z teologii patrystycznej, Opole 2001, ss. 303; kolokwium: Wydział Teologiczny UO, Opole 2002.

7. Żelazny Jan ks., Biskup Ojcem. Zarys eklezjologii syryjskiej na podstawie Konstytucji Apostolskich, Kraków 2006, ss. 296; kolokwium: Wydział Teologiczny PAT, Kraków 2006 (recenzent wyznaczony przez Centralną Komisję ds. Stopni i Tytułów 24 kwietnia 2006 r.).

8. Szulc Franciszek ks., Syn Boży w „Pasterzu” Hermasa. Świadectwo chrystologii judeochrześcijańskiej, Katowice 2006, ss.198; kolokwium: Wydział Teologiczny UO, Opole 2007 (recenzent wyznaczony przez Centralną Komisję ds. Tytułu Naukowego i Stopni Naukowych 18 grudnia 2006 r.).

9. Strękowski Stanisław, Sofiologia św. Grzegorza z Nyssy. Elementy teologii trynitarnej $i$ antropologii $w$ Homiliach do Pieśni nad pieśniami, Kraków 2006, ss. 396; kolokwium: Wydział Nauk Historycznych i Społecznych UKSW, Warszawa 2007 (recenzent wyznaczony przez Centralną Komisję ds. Stopni i Tytułów 4 kwietnia 2007 r.).

10. Zagórski Dariusz ks., Model doskonalenia chrześcijańskiego w świetle eksportacji pastoralnych Grzegorza z Nazjanzu, Toruń 2007, ss. 277; kolokwium: Wydział Teologii KUL, Lublin 2008 (recenzent wyznaczony przez Centralną Komisję ds. Stopni i Tytułów 20 lutego 2008 r.). 
11. Kasprzak Dariusz OFMCap, Duszpasterze V wieku. Studium porównawcze myśli pasterskiej św. Piotra Chryzologa i Salwiana z Marsylii, Kraków 2008, ss. 323; kolokwium: Wydział Teologiczny PAT, Kraków 2008 (recenzent wyznaczony przez Centralną Komisję ds. Stopni i Tytułów 6 maja 2008 r.).

12. Jaśkiewicz Grzegorz ks., Doketyzm jako wyraz relatywizmu w teologii, Ząbki 2009, ss. 488; kolokwium: Wydział Teologii UKSW, Warszawa 2009.

13. Grzeszczak Jan ks., Pomiędzy utopia i eschatologicznq nadzieja. Idea papieża anielskiego $w$ średniowiecznym i renesansowym profetyzmie, Poznań 2008, ss. 429; kolokwium: Wydział Teologiczny UAM, Poznań 2009.

14. Posacki Aleksander SJ, Ezoteryzm i okultyzm - formy dawne i nowe, Radom 2009, ss. 516; kolokwium: Wydział Teologii KUL, Lublin 2010.

15. Superrecenzent habilitacji dla Centralnej Komisji ds. Tytułu Naukowego i Stopni Naukowych, 12 maja 2004 r.

\section{c. Tytuł profesorski:}

1. Drączkowski Franciszek ks., Wydział Teologii KUL, Lublin 1992.

2. Częsz Bogdan ks., Wydział Teologiczny PAT, Kraków 1999.

3. Miśkiewicz Maria, Wydział Kościelnych Nauk Historycznych i Społecznych ATK, Warszawa 1999.

4. Szram Mariusz ks., Wydział Teologii KUL, Lublin 2010.

\section{Udział w konferencjach i sesjach krajowych:}

1. „Tłumaczenie tekstów starochrześcijańskich”, Międzywydziałowy Zakład Badań nad Antykiem Chrześcijańskim KUL, Włocławek, 3-4 XI 1971 r. (referat: Ruch przekladowy w zakresie języka koptyjskiego).

2. „Modlitwa starożytnych chrześcijan”, wspólne sympozjum: Sekcji Patrystycznej i Międzywydziałowego Zakładu Badań nad Antykiem Chrześcijańskim KUL - Katedr Patrologii ATK, Tarnów, 19-21 IX 1978 r. (referat: Problem modlitwy $w$ kultach misteryjnych $i$ w tekstach gnostyckich z Nag-Hammadi).

3. „Chrystocentryzm i chrystologia III i IV wieku”, Sekcja Patrystycza, Gdańsk-Oliwa 20-21 IX 1984 r. referat: Ćwiczenia z patrologii).

4. „Chrześcijanie a życie publiczne w Cesarstwie Rzymskim III i IV wieku", Instytut Historii Kościoła KUL, Lublin, 20-21 III 1985 r. (referat: Udziat chrześcijan $w$ widowiskach, teatralnych $w$ ocenie greckich pisarzy kościelnych).

5. „Wybrane problemy społeczne pierwszych chrześcijan”, Katedry Patrologii Wydziału Kościelnych Nauk Historycznych i Społecznych ATK, Warszawa, 20 II 1989 r. (referat: Praca charytatywna pierwszych chrześcijan).

6. Referat: Koptyjska biblioteka z Nag Hammadi, Oddział Polskiego Towarzystwa Orientalistycznego, Kraków 1988. 
7. „Kapłaństwo w starożytności chrześcijańskiej”, Międzywydziałowy Zakład Badań nad Antykiem Chrześcijańskim KUL, Lublin, 29-30 X 1991 r. (referat: Przygotowanie do kapłaństwa w IV $i$ V wieku w Kościele Wschodnim).

8. „Asceza wczesnochrześcijańska”, Sekcja Patrystyczna, Paradyż-Gościkowo, 22-23 IX 1992 r. (referat: Asceza w listach świętego Antoniego i niektórych tekstach z Nag Hammadi).

9. „Orygenes a Biblia”, Sekcja Patrystyczna ATK, Warszawa, 10 III 1994 r. (referat: Gnostycy i Orygenes).

10. „Asceza i doskonałość chrześcijańska w nauce Ojców Kościoła”, Sekcja Patrystyczna, Gniezno, 25-26 IX 1995 r. (referat: Gnostycka motywacja ascezy $i$ walki ze złem).

11. „Gnostycyzm antyczny i współczesna neognoza”, Wydział Kościelnych Nauk Historycznych i Społecznych ATK, Warszawa, 17 X 1996 r. (referat: Elementy gnostyckie $w$ nowej religijności), organizacja sympozjum i projekt problematyki.

12. „Grzech pierworodny w nauce Ojców Kościoła”, Sekcja Patrystyczna, Kraków, 19-20 IX 1997 r. (referat: Nauka o grzechu w przekazach gnostyckich).

13. „Judeochrześcijańskie elementy w literaturze patrystycznej”, Wydział Kościelnych Nauk Historycznych i Społecznych ATK, Warszawa, 16 X 1997 r. (referat: Judeochrześcijaństwo - problem definicji).

14. „Demonologia w nauce Ojców Kościoła”, Sekcja Patrystyczna, Siedlce, 21-22 X 1998 r. (referat: Stwórca świata i szatan w pismach gnostyków).

15. Wręczenie Księgi Jubileuszowej Ks. prof. Henrykowi Wójtowiczowi, ATK, Warszawa, 19 II 1998 r. (referat: Biblioteka z Nag Hammadi: formy literackie).

16. „Kobieta w starożytności chrześcijańskiej”, Wydział Kościelnych Nauk Historycznych i Społecznych ATK, Warszawa, 22 X 1998 r. (referat: Kobieta $w$ gminach chrześcijańskich II i III wieku. Instytucja wdów, dziewic i diakonis).

17. „Polskie studia nad antykiem chrześcijańskim”, Międzywydziałowy Zakład Badań nad Antykiem Chrześcijańskim KUL, Lublin, 25-26 V 1999 r. (referat: Polskie badania nad gnostycyzmem).

18. „Millenaryzm wczesnochrześcijański”, Sekcja Patrystyczna, Legnica, 2425 IX 1999 r. (referat: Tysiac lat panowania Chrystusa na ziemi. Millenaryzm w ujęciu Ireneusza z Lyonu).

19. „Chrześcijaństwo wobec przełomu wieków”, Wydział Nauk Historycznych i Społecznych UKSW, Warszawa, 21 X 2000 r. (referat: Pax Romana i Pax Christi w ujęciu Euzebiusza z Cezarei), organizacja sympozjum i program.

20. „Przełom wieków w myśli patrystycznej”, Wydział Nauk Historycznych i Społecznych UKSW, Warszawa, 24 X 2001 r. (referat: Chrześ- 
cijaństwo wobec pluralizmu świata antycznego; religijność pogańska i chrześcijańska).

21. „Miasto w starożytności”, Zakład Historii Społeczeństw Antycznych i Komisja Historii Starożytnej Polskiego Towarzystwa Historycznego, Poznań, 19-21 IX 2002 r. (referat: Chrześcijaństwo jako religia miejska $w$ świetle pism Cypriana z Kartaginy).

22. „Chrześcijaństwo II-V wieku wobec antycznych tradycji ezoterycznych”, Wydział Nauk Historycznych i Społecznych UKSW, Warszawa, 16 X 2002 r. (referat: Ezoteryzm gnostyków).

23. „Byt czy dobro? Metamorfozy neoplatonizmu”, Międzynarodowa Konferencja Wydziału Filozofii KUL i Międzywydziałowego Zakładu Badań nad Antykiem Chrześcijańskim KUL, Lublin, 7-10 X 2003 r. (referat: Gnostische Begriff des Guten und des Bösen in der Plotins Polemik).

24. „Grecy, Rzymianie ich sąsiedzi”, Komisja Historii Starożytnej Polskiego Towarzystwa Historycznego, Instytut Historyczny UWr, Wrocław, 21-23 IX 2005 r. (referat: Szenute wobec pogan i heretyków).

25. „Wczesnochrześcijańska literatura orientalna”, Sekcja Patrystyczna, Łódź, 22 IX 2007 r. (referat: Koptyjskie kodeksy odkryte w Górnym Egipcie przez polskich archeologów, ich wartość historyczna i literacka).

26. Referat: Ewangelia Judasza i znaczenie jej odkrycia $w$ badaniach nad gnostycyzmem chrześcijaństwa, Komisja Badań nad Antykiem Chrześcijańskim KUL, Lublin, 18 X 2007 r.

27. „Świętość a dobro”, Polskie Towarzystwo Teologiczne, Kraków, 20 XI 2008 r. (referat: Gnoza zbawcza i świętość).

28. Referat: Św. Paweł nauczycielem gnostyków?, Komisja Badań nad Antykiem Chrześcijańskim KUL, Lublin, 19 XI 2009 r.

\section{Współpraca z ośrodkami naukowymi w kraju i zagranicą:}

1. Współpraca z Zakładem Egiptologii Instytutu Orientalistycznego Uniwersytetu Warszawskiego w latach 1974-1998 (w zakresie studiów i tłumaczeń z języka koptyjskiego).

2. Współpraca z Patristische Kommission der Akademien der Wissenschaften Arbeitsstelle Bonn w programie „Bibliographia Patristica” w latach 1975-1990 (w zakresie informacji naukowej, przeprowadzanie selekcji i opisy polskich publikacji patrystycznych na użytek międzynarodowy).

3. Staż naukowy (roczne stypendium Archidiecezji Paderborn) w Moehler-Institut, Paderborn 1975.

4. Współpraca z Berliner Arbeistkreis für Koptisch-gnostischen Schriften (pod kierunkiem Prof. H.M. Schenke, Berlin (Wschodni) w latach 1980-1982).

5. Udział w I Kongresie Koptologicznym w Kairze w 1976 r. (referat: La coptologie en Pologne). 
6. Współpraca z czasopismem egiptologicznym „Enchoria” (Würzburg) w latach 1984-1990, w zakresie informacji naukowej.

7. Udział w III Kongresie Koptologicznym w Warszawie w 1984 r. (referat: Die Taufe als Schweigen. Zur Theologie der Taufe im Tractatus tripartitus), współorganizator Kongresu ze strony Akademii Teologii Katolickiej w Warszawie.

8. Wykład na Wydziale Teologii Katolickiej w Moguncji: Gastvorlesung an der Universität in Mainz: 19 VI 1990 r. (referat: Nag Hammadi: Gnosis und Mönchtum).

9. Seminarium patrystyczne Un texte d'Irénée et le témoignage de Nag Hmmadi (Interpretacja gnostyckich tekstów z Nag Hammadi) i wykład w Institut Catholique de Paris: 2-3 II 1995 r. (referat: L'Origène et les gnostiques).

10. Wykład w Instytucie Dölgera w Bonn: Antonius-Briefe und Nag Hammadi-Texte (24 VI $1988 \mathrm{r}$.).

11. Grant ministerialny: Biblioteka z Nag Hammadi. Kodeksy I i II; projekt badawczy PB 580/TE/2006-2008.

7. Prace redakcyjne. Od 1969 r., czyli od chwili powstania, Ksiądz Profesor Myszor należał do zespołu redakcyjnego patrystycznej serii wydawniczej ATK (obecnie UKSW) „Pisma Starochrześcijańskich Pisarzy”, w ramach której ukazywały się polskie przekłady literatury wczesnochrześcijańskiej; w serii tej, oprócz prac redakcyjnych, opracowywał merytorycznie komentarze i własne tłumaczenia. W 1977 r. założył w ATK w Warszawie serię Studia Antiquitatis Christianae, w której jako redaktor naczelny kierował pracą redakcyjną do 16 tomu włącznie (1/1977 - 16/2001): w serii tej publikował między innymi wyróżnione prace habilitacyjne, doktorskie i magisterskie. W latach 1981-1995 był też redaktorem naczelnym „Śląskich Studiów Historyczno-Teologicznych” w Katowicach (14/1981 - 27/28/1994/1995), a od 2005 r. kieruje redakcją serii „Studia Antiquitatis Christianae. Series Nova” (Katowice).

\section{Nagrody i wyróżnienia:}

1983 - nagroda zespołowa II stopnia Ministra Nauki, Szkolnictwa Wyższego

i Techniki za osiagnięcia w dziedzinie badań naukowych.

1990 - Medal Komisji Edukacji Narodowej (Ministra Edukacji Narodowej).

2001 - Złoty Krzyż Zasługi przyznany przez Prezydenta RP.

2003 - godność Kapelana Jego Świątobliwości Jana Pawła II.

2005 - Złota Odznaka za zasługi dla Uniwersytetu Śląskiego (nagroda Rektora Uniwersytetu Śląskiego).

2006 - nagroda zespołowa Ministra Nauki i Szkolnictwa Wyższego za współautorstwo syntezy Literatura Grecji starożytnej (t. I i II), nagroda na wniosek Wydziału Humanistycznego KUL. 
2009 - Księga Jubileuszowa Omnia tempus habent, ss. 594 (Wydział Teologiczny UŚ) z okazji 40-lecia pracy naukowej.

2012 - Księga Jubileuszowa - 57 tom „Vox Patrum” (Sekcja Patrystyczna, Rada Naukowa „Vox Patrum”) z 40-lecia pracy naukowej i 70-lecia urodzin.

2012 - Krzyż Kawalerski Orderu Odrodzenia Polski, przyznany przez Prezydenta RP.

\section{Przynależność do stowarzyszeń:}

1. Sekcja Patrystyczna przy Komisji Episkopatu Polski d/s Nauki Katolickiej, od $1977 \mathrm{r}$.

2. Polskie Towarzystwo Teologiczne w Krakowie, od $1981 \mathrm{r}$.

3. Association Internationale d'Etudes Patristiques, od $1984 \mathrm{r}$.

4. Komisja Badań nad Antykiem Chrześcijańskim KUL (od 1994 r.)

5. International Association of Byzantine Studies, od $1996 \mathrm{r}$.

6. Komitet Nauk Teologicznych PAN (w latach 2004-2012)

7. Komitet Nauk o Kulturze Antycznej. Sekcja Bizantynologiczna PAN, członek od $1988 \mathrm{r}$.

Ludmiła Lach-Bartlik 